\title{
ФОТОИНИЦИИРОВАННОЕ ОКИСЛЕНИЕ ЛИНЕИНЫХ АЛКИЛБЕНЗОЛСУЛЬФОНАТОВ В ВОДНОЙ СРЕДЕ
}

V. TSEKULAJEV. LINEAARSETE ALKUCLBENSOOLSULFONAATIDE FOTOINITSIEERITUD OKSU. DEERUMINE VEES

V. TCHEKULAYEV. PHOTOINITIATED OXIDATION OF LINEAR ALKYLBENZOSULPHONATES IN WATER MEDIA

\author{
Представлена М. Губергрицем
}

Одним из важнейших природных факторов, под воздействием которого происходит естественное самоочищение водоемов от ПАВ, является УФ-составляющая светового излучения. В настоящем сообщении предлагаются к рассмотрению результаты первого этапа узучения кинетики и предварительные соображения к механизму фотоинициированного окисления линейных алкилбензолсульфонатов натрия (АБС) в водной среде. Нами синтезирована серия из 5 АБС с числом атомов углерода в линейной алкильной цепи от 8 до 12. Синтез 1-фенилалканов проводился по методике, описанной в [']. Методика кинетического исследования заключалась в облучении в токе кислорода водных растворов АБС в термостатированном реакторе - трехгорлой конической колбе с притертой кварцевой крышкой: варьирование концентрации растворов от 5 до 500 мг/ $\Omega$, УФ-излучение ртутно-кварцевой лампы СВД-120A в широком диапазоне. Основная часть эксперимента проводилась при $25 \pm 0,5^{\circ} \mathrm{C}$ и интенсивности облучения $10^{16} \kappa в а н т / м \Omega \cdot c$. Концентрация исходного АБС и ее изменение определялись двумя способами: колориметрированием растворенного в хлороформе окрашенного комплекса с метиленовой синей (MC) и спектрофотометрически на приборе «Specord UV VIS».

Содержание перешедшего в раствор сульфат-аниона определялось титрованием нитратом свинца в присутствии дитизона.

Обработка полученных экспериментальных данных (по убыли концентрации исходного АБС во времени) свидетельствует о первом кинетическом порядке суммарной реакции фотоинициированного окисления изученных гомологов. Однако следует отметить, что концентрационный порядок реакции, рассчитанный по начальным скоростям, составлял 0,63 для всех синтезированных АБС. Установлено закономерное снижение реакционной способности АБС по мере увеличения размеров алкильного заместителя, отмеченное при любой из изученных исходных концентраций ПАВ в растворе (рисунок). Кроме того, существенное влияние 


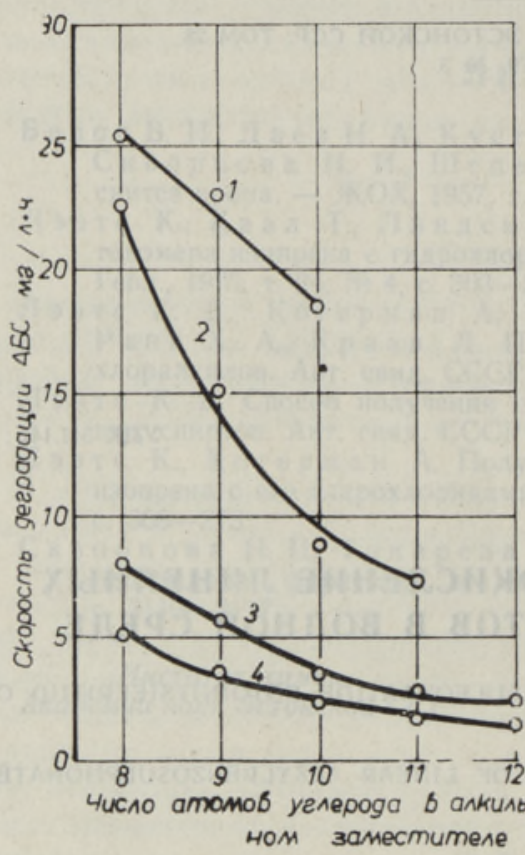
В данном случае она невелика и составляет для $n$-октила 1,65 ккал/моль. Таким образом, повышение температуры в пределах $15-45^{\circ}$ лишь незначительно стимулирует окисление изученных АБС.

В табл. 1 приведены результаты исследования влияния $\mathrm{pH}$ водной среды на период полупревращения $n$-октилбензолсульфоната натрия. В опытах были использованы фосфатный и солянокислый буферы. Со снижением $\mathrm{pH}$ среды скорость окисления АБС несколько повышалась примерно на $15 \%$.

Существенным элементом суммарного процесса деградации АБС является их фотоинициированное десульфирование (табл. 2). Степень десульфирования сопоставлена с реакционной способностью соединения, однако заметного влияния величины алкильного заместителя на этот показатель (в среднем на уровне $30 \%$ ) установить не удалось.

таблица 1

Таблица 2

Зависимость скорости фотоокисления $\boldsymbol{n}$-октилбензолсульфоната натрия от $\mathrm{pH}$ среды (исходная концентрация $100 \mathrm{mz} / \pi ; 25^{\circ} \mathrm{C}$ )

\begin{tabular}{|c|c|c|}
\hline $\mathrm{pH}$ & 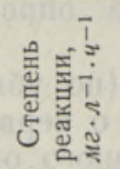 & 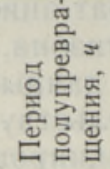 \\
\hline
\end{tabular}

$\begin{array}{lll}8,14 & 11,8 & 5,89 \\ 6,16 & 12,7 & 5,45 \\ 1,38 & 13,6 & 5,11\end{array}$

Кинетика фотодесульфирования АБС в водной среде при исходной концентрации 500 мг/л

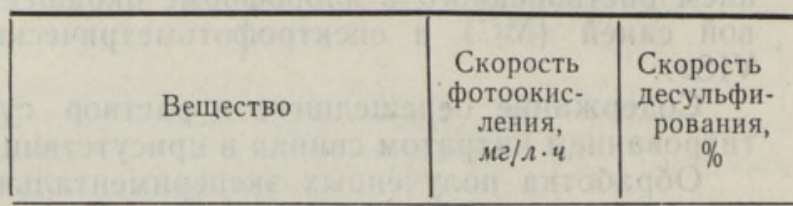

Бензолсульфонат натрия n-Октилбензолсульфонат натрия

n-Нонилбензолсульфонат натрия

о-Нонилбензолсульфонат натрия $n$-Децилбензолсульфонат натрия
58,75 27

25,58

31

23,1

31

19,2

18,55 35 
Нами исследовано влияние кислорода на процесс фотоинициированной деградации АБС. Эксперимент проведен с $n$-октилом при концентрации 100 мг/л, температуре $25^{\circ}$, интенсивности облучения $1 \cdot 10^{16} \kappa в а н т / м \Omega \cdot c$ в среде аргона (после длительной продувки им системы с гидравлическим затвором) и в контакте с воздухом. Скорость деградации этого АБС в среде аргона составляет 22,38 мг/л.ч (с MC) и $32,5 м 2 / \Omega \cdot$, по УФ-спектрам, в атмосфере же воздуха она оказывается заметно сниженной - до 15,2 мг/л.ч при определении с MC и 25,7 мг/л:ч, по данным спектрального анализа. Таким образом, по предварительным данным, которые требуют дальнейшего уточнения, наличие кислорода снижает скорость фотоинициированного превращения АБС.

Рассмотренные результаты и установленные кинетические закономерности позволяют предположительно судить об основных путях превращения АБС в фотоинициированном окислительном процессе. Одним из них, очевидно, является охарактеризованное выше фотоинициированное десульфирование, для которого, по данным $\left[{ }^{2}\right]$, можно представить два возможных гипотетических механизма.

Во-первых, это гидролитическое отщепление сульфогруппы:

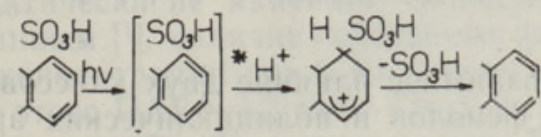

Bo-вторых, возможен гомолитический разрыв связи $\mathrm{Ar}-\mathrm{S}$ в фотовозбужденной молекуле сульфокислоты.

Второй важный элемент в суммарном фотоокислительном превращении АБС - это разрыв ароматического ядра молекулы. О его протекании и, более того, кинетике можно судить по снижению интенсивности полосы поглощения при 224 нм в УФ-спектре, которая отвечает свойствам ароматического кольца.

Таким образом, результаты приведенного исследования свидетельствуют о сложном механизме явлений, наблюдающихся при фотоинициированной деградации алкиларилсульфонатов даже в простейших модельных системах, и о необходимости дальнейшего его изучения, в частности исследования структуры получаемых продуктов реакции.

\section{Л ИТ Е РА Т У РА}

1. Том сон Р. Синтез 1-, 2-, 3-, 4-, 5-, 6-фенилдодеканов. - Изв. АН ЭССР. Сер. физ.-мат. и техн. н., 1966, т. 15, № 3, с. 447-453.

2. С тудзи нский О. П., Ельцов А. В., Ртищев Н. И., Фомин Г. В. Фотохимия арилсульфонильных соединений. - Успехи химии, 1974, т. XLIII, вып. 3, c. $401-429$.

Ннститут химии

Академии наук Эстонской ССР
Поступила в редакцию $16 / \mathrm{I} 1979$ 